\title{
Crude Alkaloid and Saponin Extracts of Agrimonia eupatoria Plant as Control Measure in Stainless Steel Corrosion in Hydrogen Tetraoxosulphate (VI) Acid Rich Area
}

\author{
B.U. Ugi1,*, M.E. Obeten ${ }^{1}$, Ekerete Jackson ${ }^{2}$ \\ ${ }^{1}$ Department of Chemical Sciences, Cross River University of Technology, P.M.B. 1123 Calabar, Nigeria. \\ 2Department of Chemistry, University of Uyo, P. M. B. 1017 Uyo, Akwa Ibom State, Nigeria.
}

\section{ART ICLE DETAILS}

Article history:

Received 27 February 2018

Accepted 24 March 2018

Available online 02 April 2018

\section{Keywords:}

Polarization

Inhibition Efficiency

Gibbs Free Energy

Saponins

\begin{abstract}
A B S T R A C T
The corrosion and inhibition behavior of carbon steel in hydrogen tetraoxosulphate (IV) acid rich area in the presence of crude saponins and alkaloids extracts of Agrimonia eupatoria leaves have been studied using mass loss and potentiodynamic polarization techniques. The extracts presented good inhibition ability on the carbon steel metal in hydrogen tetraoxosulphate (IV) acid environment with the alkaloids inhibiting more compared to saponins with maximum inhibition efficiency of $97.6 \%$ and $87.8 \%$ respectively at $7.5 \mathrm{~g} / \mathrm{L}$ concentration. There was a noticeable increase in inhibition mitigation potential of the inhibitors with increasing concentration of extracts. A physical adsorption mechanism was recorded by the inhibitor/carbon steel interface and the Langmuir adsorption isotherm was well obeyed with correlation coefficient at approximately unity. The inhibitors proved to be stable ones on the metal and a spontaneous reaction process was recorded from the data of the Gibbs free energy of adsorption.
\end{abstract}

\section{Introduction}

Most of the industrial cooling water system in refineries, chemical processing plants, and petrochemical and fertilizer industries use ground water for cooling purposes. In this kind of situation, organic and inorganic inhibitors are used to reduce the corrosive action of acids. Some of the organic inhibitors available are considered to be very toxic and expensive because of its carcinogenic properties. Hence, a need exists for finding the environmentally and eco-friendly formulations for the control of corrosion [1-4]. These have attracted many researchers. The plant extracts are considered as an incredibly rich source of environmentally acceptable corrosion inhibitors. This area of research is of much importance because in addition to being environmentally friendly and ecologically acceptable, that can be extracted by simple procedures with low cost. Corrosion damage can be prevented by using various methods such as upgrading materials, blending of production fluids, process control and chemical inhibition $[1,2]$. The known effects of most synthetic corrosion inhibitors are the motivation for the use of some natural products. Natural products are nontoxic, biodegradable and readily available. So many natural products have been used widely as inhibitors in the corrosion of metals especially steel, aluminum, iron, etc. Corrosion inhibition investigation of natural inhibitors is particularly interesting because they are inexpensive, ecologically friendly, and possess no threat to the environment [3-6].

\section{Experimental Methods}

\subsection{Pre-Preparation Extraction of Agrimonia eupatoria Sample}

The fresh leaves of Agrimonia eupatoria obtained from a garden in Cross River University of Technology farm in Calabar were washed and cut into small cheeps and dried in oven at $50^{\circ} \mathrm{C}$. After the drying of the leaves, they were put through grinding to obtain a powdered sample. Conventional mortar and pestle was used for grinding, followed by the use of electric blender to reduce particle size of sample. The powdered sample was extracted using the maceration extraction process. The powdered plant material was soaked in a stoppered container with distilled water as the extraction solvent and allowed to stand at room temperature for a period of 5 days with frequent agitation. This process allowed for softening and 
surface after immersion was rinsed with constant scrubbing in distilled water to remove scales. The washed carbon steel samples were cleaned by washing with absolute ethanol, rinsed in acetone and allowed to dry in the air before re-weighing. The surface coverage $(\theta)$ and inhibition efficiency (\% IE) of the inhibitor were derived using equation respectively.

$$
\theta=1-\left(\frac{w_{1}}{w_{0}}\right) \quad \% I E=1-\left(\frac{w_{1}}{w_{0}}\right) \times 100
$$

\subsection{Electrochemical Determination}

The potentiodynamic polarization experiment was conducted using a three-electrode electrochemical cell assembly. Well abraded stainless steel sheets with a surface area dimension of $1 \mathrm{~cm}^{2}$ was employed as the working electrode (WE) while a platinium rod was employed as the counter electrode (CE) and saturated calomel electrode as the reference electrode (RE). The RE was coupled with a lugging capillary to ensure suitable geometry of the cell electrodes with minimum potential drop. The stainless steel sheet serving as the WE was immersed in the test solution for 1 hour to attain a steady open circuit potential (OP) before electrochemical measurement. Potentiodynamic anodic and cathodic polarization curves were obtained at a scan rate of $0.001 \mathrm{Vs}^{-1}$ in the potential range from -1.0 to $0 \mathrm{~V}$ relative to the corrosion potential $\left(\mathrm{E}_{\text {corr }}\right)$. Potentiodynamic polarization studies were performed using electrochemical analyzer Gamry DE190I instrument.

\section{Results and Discussion}

\subsection{Results from Mass Loss Experiments}

The crude alkaloid and saponin inhibitors were tested for six different concentrations including a blank that served as a control $(0.5 \mathrm{~g} / \mathrm{L}, 1.0 \mathrm{~g} / \mathrm{L}$, $2.0 \mathrm{~g} / \mathrm{L}, 3.5 \mathrm{~g} / \mathrm{L}, 5.0 \mathrm{~g} / \mathrm{L}$ and $7.5 \mathrm{~g} / \mathrm{L}$ ) and the result is presented in Tables 1 and 2 . The addition of both inhibitors increased the percentage inhibition efficiency following the time of immersion [7-11]. It is observed that the corrosion rates of stainless steel decreased, surface coverage and inhibition efficiency of the inhibitors increased following increase extract concentration. These results are in accordance with the results obtained from variation of weight loss of metal with time of immersion and inhibitor concentrations respectively (Figs. 1-4).

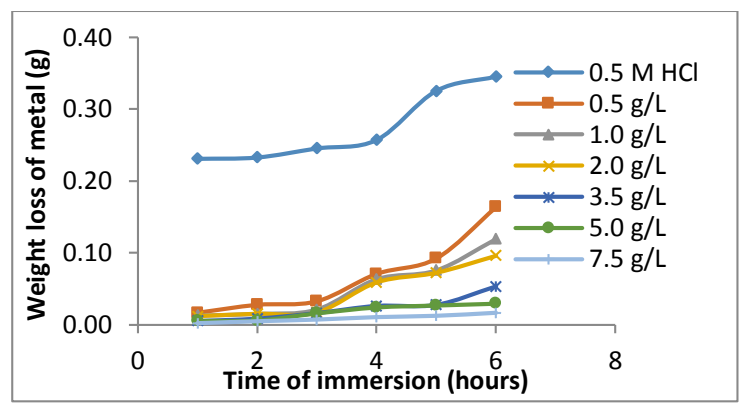

Fig. 1 Variation of weight with time of immersion for the corrosion of stainless steel in $1 \mathrm{M} \mathrm{H}_{2} \mathrm{SO}_{4}$ containing various concentrations of crude alkoloids at $303 \mathrm{~K}$

The inhibitors showed maximum inhibition efficiency of $97.6 \%$ for crude alkaloids and $87.8 \%$ for crude saponins respectively, both at an optimum concentration of $7.5 \mathrm{~g} / \mathrm{L}$. This may be due to the strong adsorption of phytochemical constituents of the extracts on the anodic/or cathodic sites of metal surface, increase in anodic/cathodic over voltage and the formation of a protective barrier film [12-14].

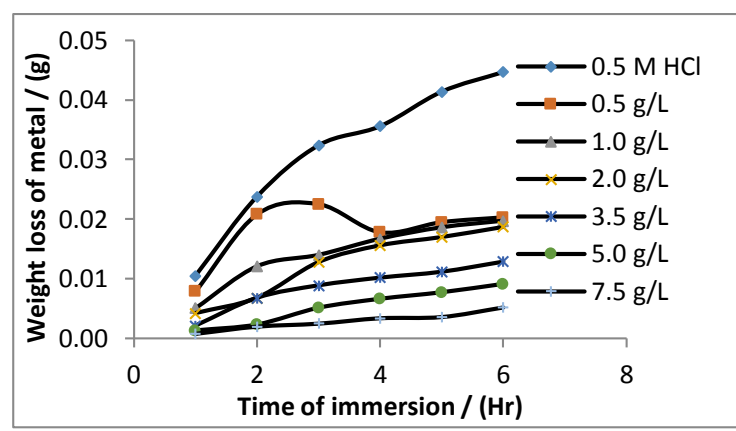

Fig. 2 Variation of weight with time of immersion for the corrosion of stainless steel in $1 \mathrm{M} \mathrm{H}_{2} \mathrm{SO}_{4}$ containing various concentrations of crude saponins at $303 \mathrm{~K}$ https://doi.org/10.30799/jespr.120.18040103

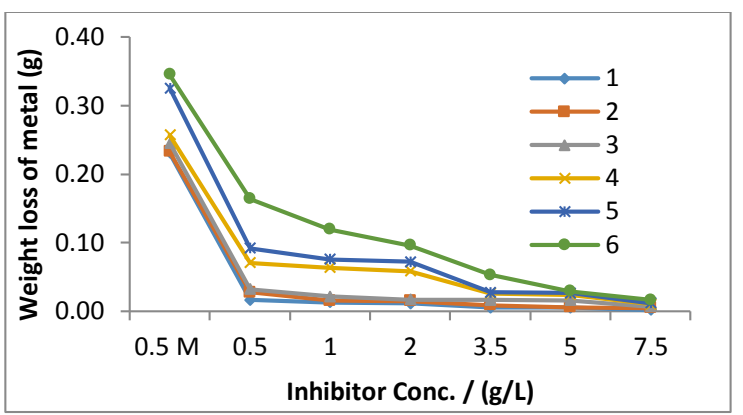

Fig. 3 Variation of weight with inhibition concentration for the corrosion of stainless steel in $1 \mathrm{M} \mathrm{H}_{2} \mathrm{SO}_{4}$ containing various concentrations of crude alkaloid at $303 \mathrm{~K}$

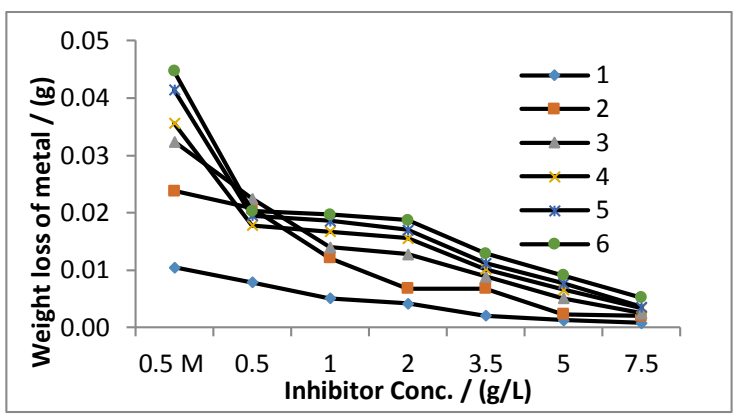

Fig. 4 Variation of weight with inhibition concentration for the corrosion of stainless steel in $1 \mathrm{M} \mathrm{H}_{2} \mathrm{SO}_{4}$ containing various concentrations of crude saponins at $303 \mathrm{~K}$

Table 1 Results obtained from weight loss experiment showing corrosion rate of stainless steel, surface coverage and inhibition efficiency of AEAEL in $1 \mathrm{M} \mathrm{H}_{2} \mathrm{SO}_{4}$ environment

\begin{tabular}{llll}
\hline Inhibitor Conc. (g/L) & CR $\left(\mathrm{mg} / \mathrm{cm}^{2} / \mathrm{hr}\right)$ & $\theta$ & IE (\%) \\
\hline $0.5 \mathrm{M} \mathrm{HCl}$ & 0.5933 & - & - \\
0.5 g/L AEAEL & 0.4824 & 0.187 & 18.7 \\
1.0 g/L AEAEL & 0.4322 & 0.272 & 27.2 \\
2.0 g/L AEAEL & 0.3108 & 0.476 & 47.6 \\
3.5 g/L AEAEL & 0.2099 & 0.646 & 64.6 \\
5.0 g/L AEAEL & 0.1310 & 0.779 & 77.9 \\
7.5 g/L AEAEL & 0.0143 & 0.976 & 97.6 \\
\hline
\end{tabular}

Table 2 Results obtained from weight loss experiment showing corrosion rate of stainless steel, surface coverage and inhibition efficiency of SEAEL in $1 \mathrm{M} \mathrm{H}_{2} \mathrm{SO}_{4}$ environment

\begin{tabular}{llll}
\hline Inhibitor Conc. (g/L) & CR $\left(\mathrm{mg} / \mathrm{cm}^{2} / \mathrm{hr}\right)$ & $\theta$ & IE (\%) \\
\hline $0.5 \mathrm{M} \mathrm{HCl}$ & 0.1560 & - & - \\
$0.5 \mathrm{~g} / \mathrm{L} \mathrm{SEAEL}$ & 0.0760 & 0.513 & 51.3 \\
1.0 g/L SEAEL & 0.0650 & 0.583 & 58.3 \\
2.0 g/L SEAEL & 0.0470 & 0.699 & 69.9 \\
3.5 g/L SEAEL & 0.0390 & 0.750 & 75.0 \\
5.0 g/L SEAEL & 0.0360 & 0.769 & 76.9 \\
7.5 g/L SEAEL & 0.0190 & 0.878 & 87.8 \\
\hline
\end{tabular}

\subsection{Potentiodynamic Polarization Result}

The potentiodynamic polarization curves of mild steel immersed in the absence and presence of inhibitor are shown in Figs. 5 - 6. The corrosion parameters namely corrosion potential $\left(\mathrm{E}_{\text {corr }}\right)$, corrosion current $\left(\mathrm{I}_{\text {corr }}\right)$ and percentage of inhibition efficiency calculated from Tafel plots are given in Table 3. The inhibition efficiency is defined as [15-18].

$$
\% \mathrm{IE}=\frac{I o_{\mathrm{Corr}}-I i_{\mathrm{Corr}}}{I o_{\mathrm{Corr}}} \times 100
$$

where $\mathrm{I}_{0 \text { corr }}$ and $\mathrm{I}_{\text {icorr }}$ are the corrosion current density values without and with inhibitor respectively, which were obtained from the extrapolation of the anodic and cathodic Tafel plots to the value of $\mathrm{E}_{\text {corr }}$ by the software provided with the equipment. Anodic shift of the $E_{\text {corr }}$ values was also observed from the curves as shown in Figs. 5-6, indicative that both AEAEL and SEAEL acted as mixed type inhibitors [1, 19-21]. This was confirmed from the decreasing values of the anodic and cathodic slopes as shown in Table 3, which signifies decrease in anodic dissolution of metal and cathodic hydrogen evolution [22-27]. Moreover in the presence of the inhibitor system, the corrosion current density decreased compared to the free system $\left(1 \mathrm{M} \mathrm{H}_{2} \mathrm{SO}_{4}\right.$.) These observations are indicative of the fact that addition of AEAEL and SEAEL to $1 \mathrm{M} \mathrm{H}_{2} \mathrm{SO}_{4}$ solution has reduced the anodic dissolution and the cathodic hydrogen evolution reaction of stainless steel in the acid medium [28-31]. 


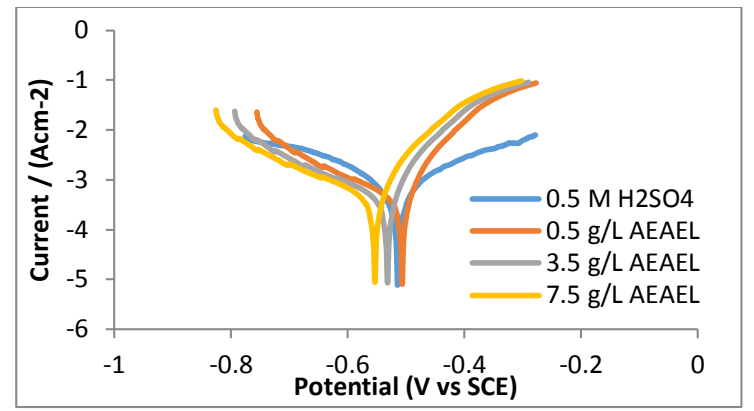

Fig. 5 Tafel plots of stainless steel immersed in $1 \mathrm{M} \mathrm{H}_{2} \mathrm{SO}_{4}$ with and without AEAEL

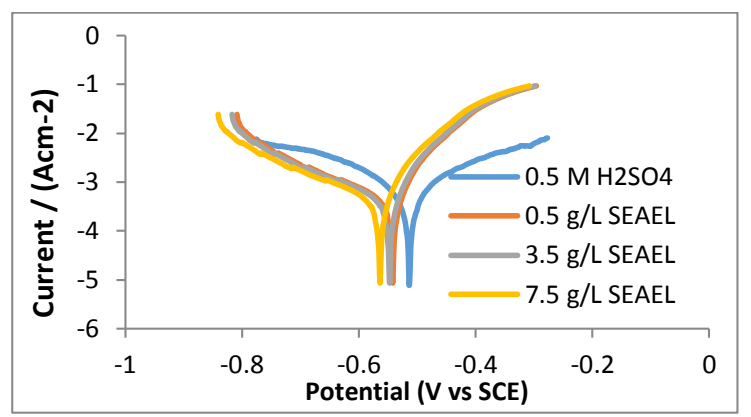

Fig. 6 Tafel plots of stainless steel immersed in $1 \mathrm{M} \mathrm{H}_{2} \mathrm{SO}_{4}$ with and without SEAEL

Table 3 Potentiodynamic polarization parameters for the corrosion of stainless steel in $1 \mathrm{M} \mathrm{H}_{2} \mathrm{SO}_{4}$ containing different concentrations of AEAEL and SEAEL extracts

\begin{tabular}{lllllll}
\hline Inhibitor & Conc. (g/L) & $\begin{array}{l}\mathrm{I}_{\text {corr }} \\
\left(\mathrm{mAcm}^{2}\right)\end{array}$ & $\begin{array}{l}\mathrm{E}_{\text {corr }} \\
(\mathrm{mV})\end{array}$ & $\begin{array}{l}\beta \mathrm{a} \\
(\mathrm{mV} / \mathrm{dec})\end{array}$ & $\begin{array}{l}\beta \mathrm{c} \\
(\mathrm{mV} / \mathrm{dec})\end{array}$ & $\begin{array}{l}\mathrm{IEi} \\
(\%)\end{array}$ \\
\hline \multirow{3}{*}{ AEAEL } & Blank $(0.5 \mathrm{M} \mathrm{HCl})$ & 0.320 & -228.17 & 209.1 & 186.9 & - \\
& $0.5 \mathrm{~g} / \mathrm{L}$ & 0.1110 & -101.11 & 182.3 & 177.6 & 65.31 \\
& $3.5 \mathrm{~g} / \mathrm{L}$ & 0.0537 & -98.23 & 171.5 & 162.8 & 83.44 \\
SEAEL & $7.5 \mathrm{~g} / \mathrm{L}$ & 0.0211 & -92.15 & 153.9 & 159.1 & 93.44 \\
& $0.5 \mathrm{~g} / \mathrm{L}$ & 0.1561 & -217.42 & 199.4 & 180.5 & 51.25 \\
& $3.5 \mathrm{~g} / \mathrm{L}$ & 0.1007 & -214.22 & 163.3 & 170.2 & 658.53 \\
& $7.5 \mathrm{~g} / \mathrm{L}$ & 0.0493 & -203.06 & 137.2 & 164.1 & 84.59 \\
\hline
\end{tabular}

\subsection{Adsorption Isotherm Investigations}

The surface coverage $(\theta)$ values for different concentrations of the inhibitors in $\mathrm{H}_{2} \mathrm{SO}_{4}$ medium were evaluated using the weight loss data. The data were tested graphically to find a suitable adsorption isotherm to describe the adsorption characteristics of the extracts according to several authors [32-36]. A plot of $\log (\mathrm{C} / \theta)$ against $\log \mathrm{C}$ (Fig. 6) derived from the equation,

$$
\frac{C}{\theta}=\frac{1}{k}+C
$$

It shows a straight line with correlation coefficient values at 0.99 for both inhibitors indicating adherence to Langmuir adsorption isotherm and a typical physical adsorption This result is in accordance with those obtained by few researchers [37-39]. It is also observed that although these plots are linear, the gradients are never unity, contrary to what is expected for ideal Langmuir adsorption isotherm equation. Organic molecules having polar atoms or groups which are adsorbed on the metal surface may interact by mutual repulsion or attraction and this may be advocated as the reason for the departure of the slope values from unity $[22,23]$.

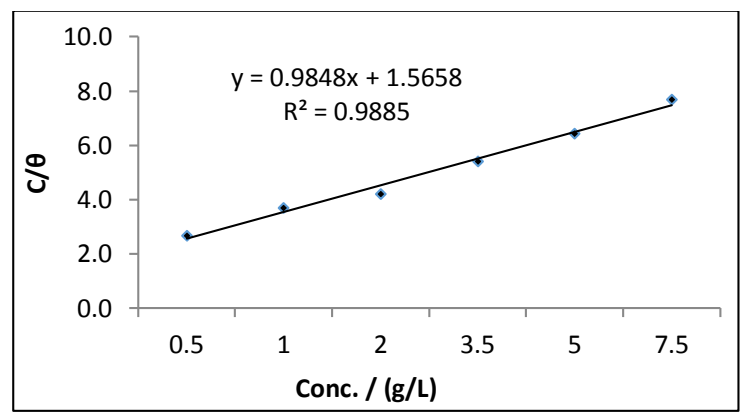

Fig. 7 Variation of $\mathrm{C} / \theta$ with concentration for the corrosion of stainless steel in $1 \mathrm{M}$ $\mathrm{H} 2 \mathrm{SO} 4$ containing various concentrations of AEAEL

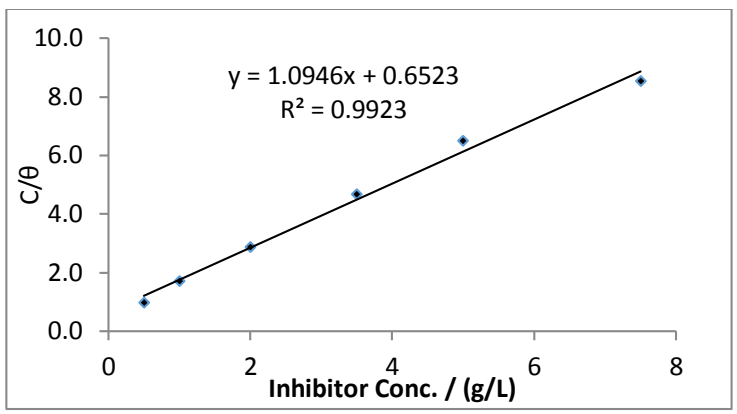

Fig. 8 Variation of $\mathrm{C} / \theta$ with concentration for the corrosion of stainless steel in $1 \mathrm{M}$ $\mathrm{H}_{2} \mathrm{SO}_{4}$ containing various concentrations of SEAEL

\section{Conclusion}

The present study leads to the following conclusion:

i. The formulation consisting of $10 \mathrm{~g}$ stock solution of crude alkaloid and saponins extracts of Agrimonia eupatoria leaves offers $97.6 \%$ and 87.8 $\%$ inhibition efficiency to stainless steel in contact with $1 \mathrm{M} \mathrm{H}_{2} \mathrm{SO}_{4}$ solution.

ii. Adsorption study reveals that the mechanism of adsorption follows Langmuir isotherm which implies a monolayer adsorption calculated from the correlation coefficient of 0.999 approximation.

iii. Thermodynamic study reveals that the inhibition process is a physically adsorbed mechanism and not a chemisorption and inhibitor shows stability and spontanous behaviour from the negative value of free energy of adsorption.

iv. Results from electrochemical analysis shows good correlation with those of mass loss experiment. The difference in the decreasing values of the anodic and cathodic slopes revealed a good surface mitigation of the metal by the both inhibitors.

\section{References}

[1] B.U. Ugi, I.E. Uwah, P.C. Okafor, Ekerete Jackson, S.E. Ejim, N.E. Nya, Sulphuric acid corrosion of mild steel in the stem extracts of Cnidoscolusa conitifolius Plant, J. Appl. Chem. Sci. Int. 5(4) (2016) 209-216.

[2] E.E. Oguzie, Enenebeaku, C.O. Akalezi, S.C. Okoro, A.A. Ayuk, E.N. Ejike, Adsorption and corrosion inhibiting effect of Dacryodis edulis extracts on lowcarbon-steel corrosion in acidic medium, Jour. Colloid Interf. Sci. 349(1) (2010) 283-292.

[3] L. Lukuvistis, A. Shaban, E. Kalman, Corrosion inhibitor, quantitative structural activity relationship, Rus. J. Electrochem. 19(2) (2003) 177-181.

[4] J.C. Mordi, M.A. Akanji, Phytochemical screening of the dried leaf extract of Cnidoscolus aconitifolius and associated changes in live enzymes induced by its administration in Wister rats, Curr. Res. J. Biol. Sci. 4(2) (2012) 153-158.

[5] A.O. Odiongenyi, S.A. Odoemelam, N.O. Eddy, Corrosion inhibition and adsorption properties of ethanol extract of Vernonia anygdalina for the corrosion of mild steel in $\mathrm{H}_{2} \mathrm{SO}_{4}$, Portugalia Electrochem. Acta 27(1) (2008) 3345.

[6] U.F. Ekanem, S.A. Umoren, I.I. Udousoro, A.P. Udoh, Inhibition of mild steel corrosion in $\mathrm{HCl}$ using pineapple heaves (Ananas comosus $\mathrm{K}$.) extract, J. Mater. Sci. 45 (2010) 55-58

[7] P. Singh, A. Singh, M.A. Quraishi, E.E. Ebenso, Cetirizine: A new and effective corrosion inhibitor for mild steel in $1 \mathrm{M} \mathrm{HCl}$ solution, Int. J. Electrochem. Sci. 7 (2012) 7065-7079.

[8] K. Anbrasi, V.G. Vascudha, Corrosion inhibition potential of Curcurbita maxima plant extract on mild steel in acid medium, Chem. Sci. Rev. Lett. 3(9) (2014) 45-51.

[9] N.O. Eddy, E.E. Ebenso, Adsorption and inhibitive properties of ethanol extract of Musa sapientum peels as a green corrosion inhibitor for mild steel in $\mathrm{H}_{2} \mathrm{SO}_{4}$ Afr. J. Pure Appl. Chem. 2(6) (2008) 46-54.

[10] M.S. Al-Otaibi, A.M. Al-Mayouf, M. Khan, A.A. Mousa, S.A. Al-Mazroa, H Alkhathlan, Corrosion inhibitory action of some plant extracts on the corrosion of mild steel in acidic media, Arab. J. Chem. 7(3) (2012) 340-346.

[11] C.A. Loto, Inhibition effect of tea (Camellia Sinensis) extract on the inhibition effect of some plant, Extracts on the acid corrosion of aluminum alloy, Afr. J. Pure Appl. Chem. 4(1) (2011) 011-016.

[12] N.S. Patel, S. Jauhariand, G.N. Mehta, S.S. Ad-Deyab, I. Warad, B. Hammouti, Mild steel corrosion by various plant extracts in $0.5 \mathrm{~m}$ sulphuric acid, Int. J. Electrochem. Sci. 8 (2013) 2635-2655.

[13] A.A. Oyagbemi, A.A. Odetola, O.I. Azeez, Phytochemical investigation and proximate analysis on the leaves of Cnidoscolus aconitifolius, J. Med. Food. 14(3) (2011) 322-324.

[14] T.J. Tuaweri, E.A. Ogbonnaya, O.O. Onyemaobi, Corrosion inhibitor of heat treated on mild steel with neem leave extract in chloride medium, Int. J. Res. Eng. Technol. 4(6) (2015) 404-409.

[15] K.C. Pradeep, K.N. Mohana, Adsorption and thermodynamic characteristics of Plumeriarubra plant extracts on mild steel corrosion in industrial water medium, Int. Res. J. Pure Appl. Chem. 3(4) (2013) 330-346. 
[16] A. Rahim, J. Kassium, Recent development of vegetal tannins in corrosion protection of iron and steel, Mater. Sci. 1 (2008) 223-231.

[17] A. Singh, A. Ishtiaque, V.K. Singh, M.A. Quraishi, Inhibition effect of environmentally benign Karanj (Pongamia pinnata) seed extract on corrosion of mild steel in hydrochloric acid solution, J. Solid State Electrochem. 15(6) (2011) 1087-1097.

[18] H.S. Gadow, M.M. Motawea, Investigation of the corrosion inhibition of carbon steel in hydrochloric acid solution by using ginger root extracts, Royal Soc. Chem. 7 (2017) 24576-24588.

[19] I.E. Uwah, B.U. Ugi, P.C. Okafor, A.I. Ikeuba, Comparative study of the corrosion inhibition and adsorption characteristics of ethanol extracts of Andrographis paniculata (king bitters) and Vernonia amygdalina (bitter leaf) on mild steel in HCl solution, Int. J. Appl. Chem. 9(1) (2013) 73-88.

[20] A.H. Kadhum, A.B. Mohamad, L.A. Hammed, A.A. Al-Amiery, N.H. San, Y.A. Musa, Inhibition of mild steel corrosion in hydrochloric acid solution by new coumarin, Materials 7 (2014) 4335-4348.

[21] H. Louis, J. Japari, A. Sadia, M. Philip, A. Bamanga, Photochemical screening and corrosion inhibition of poupartiabirrea back extract as a potential green inhibitor for mild steel in $0.5 \mathrm{~m} \mathrm{H}_{2} \mathrm{SO}_{4}$ solution, World News Nat. Sci. 10 (2017) 95-100.

[22] M. Shi, L. Hong-Qun, L. Nian-Bing, Plant extract as green corrosion inhibitors for steel in sulphuric acid, Chem. Papers 70(9) (2016) 1131-1143.

[23] C. Kamal, M. Gopalakrishnan, A bis-indol alkaloid as a green inhibitor for corrosion of mild steel in $\mathrm{HCl}$ solution from Caulerpa racemosa, J. Hazard. Mater. 2(3) (2012) 54-60.

[24] A.M. Abdel-Gaber, B.A. Abd-El-Nabey, M. Saadawy, The role of acid anion on the inhibition of the acidic corrosion of steel by lupine extract, Corr. Sci. 51(5) (2009) 1038-1042.

[25] R. Sharon, S. Narian, Protection against corrosion an introduction to electrometallurgy, Standard Publishers Distributor, Naisarak, Delhi, India, 2006, pp.53-70.

[26] A. Singh, E.E. Ebenso, M.A. Quraishi, Theoretical and electrochemical studies of metformin as corrosion inhibitor for mild steel in hydrochloric acid solution, Int. J. Electrochem. Sci. 7 (2012) 4766-4779.

[27] Y. Wehuali Yan, C. Lankun, H. Baorong, Electrochemical and quantum chemical study of purines as corrosion inhibition of mild steel in $\mathrm{HCl}$ solution, Electrochem. Acta 53 (2008) 5953-5960.
[28] K. Ghulamullah, M. Kazi, N. Newaz, J. Wan, H. Basiru, M.A. Binti, L.F. Fadhil, M.K Ghulam, Application of natural product extracts as green corrosion inhibitors for metals and alloys in acid pickling processes - A review, Int. J. Electrochem. Sci. 10 (2015) 6120-6134.

[29] J. Gopal, A. Shadma, S. Shanthi, P. Rajiv, Musa paradisica peel extract as green corrosion inhibitor for mild steel in HCl solution, Mater. Sci. 90 (2015) $107-$ 117.

[30] R. Solmaz, , M.E. Mert, , Y.B. Kardas, M. Erbil, Adsorption and corrosion inhibition effect of 1,1-thiocarbonydiimidzole on mild steel in $\mathrm{H}_{2} \mathrm{SO}_{4}$ solution and sygnergistic effect of iodide ion, Acta Physico-Chim Sinica 24(4) (2008) 1185-1190.

[31] A. Singh, V. Singh, M. Quraishi, Aqueous extract of king of bitters (Andrographis paniculata) leaves as green inhibitor for mild steel in hydrochloric acid solution, Int. J. Corr. 20(27) (2010) 214-220.

[32] A.I. Ikeuba, B.I. Ita, R.A. Etiuma, V.M. Bassey, B.U. Ugi, E.B. Kporokpo, Green corrosion inhibitors for mild steel in $\mathrm{H}_{2} \mathrm{SO}_{4}$ solution, comparative study of flavonoids extracted from Gongronema latifolium with crude extract, J. Chem. Proc. Eng. 34 (2015) 1-9.

[33] P. Mourya, B. Sitashree, M.M. Singh, Corrosion inhibition of mild steel in acidic solution by Tagetes erecta (marigold flower) extract as green inhibitor, Corr. Sci. 85 (2014) 352-363.

[34] A.O. Okewale, A. Olaitan, The use of rubber leaf extract as a corrosion inhibitor for mild steel in acidic solution, Int. J. Mater. Chem. 7(1) (2017) 5-13.

[35] S.J. Olesegun, E.A. Okoronkwo, A.E. Okotete, O.A. Ajayi, Gravimetric and electrochemical studies of corrosion inhibition potential of acid and ethanol extract of siam weed on mild steel, Leonardo J. Sci. 9(2) (2016) 25-42.

[36] A.M. Atta, G.A. El-Mahdy, H.A. Al-Lohedan, S.A. Al- Hussain, Inhibition of mild steel in acidic medium by magnetite myrrh nanocomposite, Int. J. Electrochem Sci. 9 (2014) 8446-8457.

[37] A. Peter, I.B. Obot, S.K. Sharma, Use of natural gums as green corrosion inhibitors: an overview, Int. J. Indus. Chem. 6(3) (2015) 153-164.

[38] K.V. Dakeshwar, K. Fahmida, Green approach to corrosion inhibition of mild steel in hydrochloric acid medium using extracts of spirogyra algae, Green Chem. Lett. Rev. 9(1) (2016) 52-60.

[39] A.S. Fouda, G. El-Ewady, H. Ali, Modazar as promising corrosion inhibitor of carbon steel in hydrochloric acid solution, Green Chem. Lett. Rev. 10(2) (2017) 88-100. 